\title{
KAKO PODPRETI SPREMEMBE IN NOVOSTI V KMETIJSTVU?
}

\section{NEWBIE (New Entrant netWork: Busi- ness models for Innovation, entrepre- neurship and resilience in European ag- riculture), program Horizon 2020}

Za ohranjanje vitalnosti, prožnosti in konkurenčnosti evropskega podeželja je izjemne-

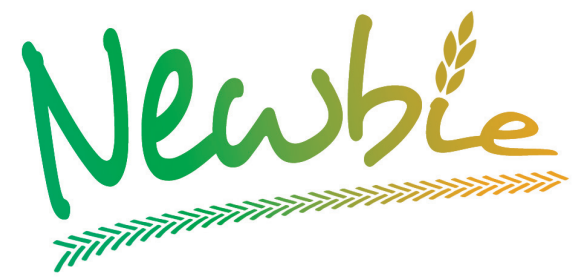
ga pomena delovanje kmetijskega sektorja: le-ta se sooča s premajhnim dotokom mladih in inovativnih kmetijskih praks. Oddelek za geografijo Filozofske fakultete Univerze v Ljubljani je kot partner v januarju 2018 pričel z izvajanjem štiriletnega projekta NEWBIE (New Entrant netWork: Business models for Innovation, entrepreneurship and resilience in European agriculture).

Osrednja ciljna skupina so novi pristopniki v kmetijstvo: mednje prištevamo novince (vsakdo, ki se povsem na novo vključi v kmetijsko dejavnost) in naslednike (se vključi $\mathrm{v}$ obstoječo kmetijo). Novi pristopniki so različnih starosti, z raznolikimi izkušnjami v kmetijstvu in z raznovrstnim dostopom do virov. Dejstvo je, da se novi pristopniki soočajo s številnimi in različnimi ovirami, kot so: dostop do kmetijske zemlje, dostop do kapitala, dostop do pravih informacij, dostop do trgov ipd. Pri novih pristopnikih nas zanima dvoje: njihov vstopni (načini vstopanja v kmetijstvo) in poslovni model (njegov razvoj in širjenje).

Projekt NEWBIE je financiran s strani EU programa za raziskovanje Horizon 2020 in povezuje deset partnerjev v devetih državah (Nemčija, Združeno kraljestvo, Bolgarija, Francija, Portugalska, Irska, Nizozemska, Belgija, Slovenija). Ker je pri projektu NEWBIE ključnega pomena prenos znanja, projektni partnerji prihajajo tako iz raziskovalnih (Wageningen Research, Katoliška univerza Leuven, Univerza za uporabne znanosti Soest iz Vestfalije, Univerza iz Evore, Inštitut James Hutton s Škotske, Univerza iz Ljubljane) kot ključnih ustanov na podeželju (Mreža podeželskih razvojnih inkubatorjev RENETA, kmetijska svetovalna služba TEAGASC, Podjetniški inkubator Goce Delčev, Zveza nemške podeželske mladine).

V strukturi, ki bo vzpostavljena s tematsko Mrežo NEWBIE (sestavljajo jo različni akterji in deležniki; gl. shematski prikaz), skrbimo za pretok znanja tako na ravni vsake partnerske države kot tudi v mednarodnem okolju (bilateralne in transnacionalne povezave). Za lažji in boljši pretok znanja med različnimi akterji in deležniki v Mreži NEWBIE ter med različnimi ravnimi, smo oblikovali dva povezovalca Mreže NEWBIE:

- Usmerjevalna skupina je zadolžena za opredelitev ključnih tematik in potek projekta na državni ravni; v Sloveniji je sestavljena iz desetih članov (osmih različnih ustanov in predstavnika novih pristopnikov) in se srečuje dvakrat letno; 
- Diskusijski krožek v vsaki državi partnerici povezuje več različnih deležnikov in akterjev, ki razpravljajo o izbrani relevantni oviri za nove pristopnike (v posamezni državi bomo izvedli osem srečanj diskusijskih krožkov).

Shematski prikaz delovanja projekta NEWBIE.

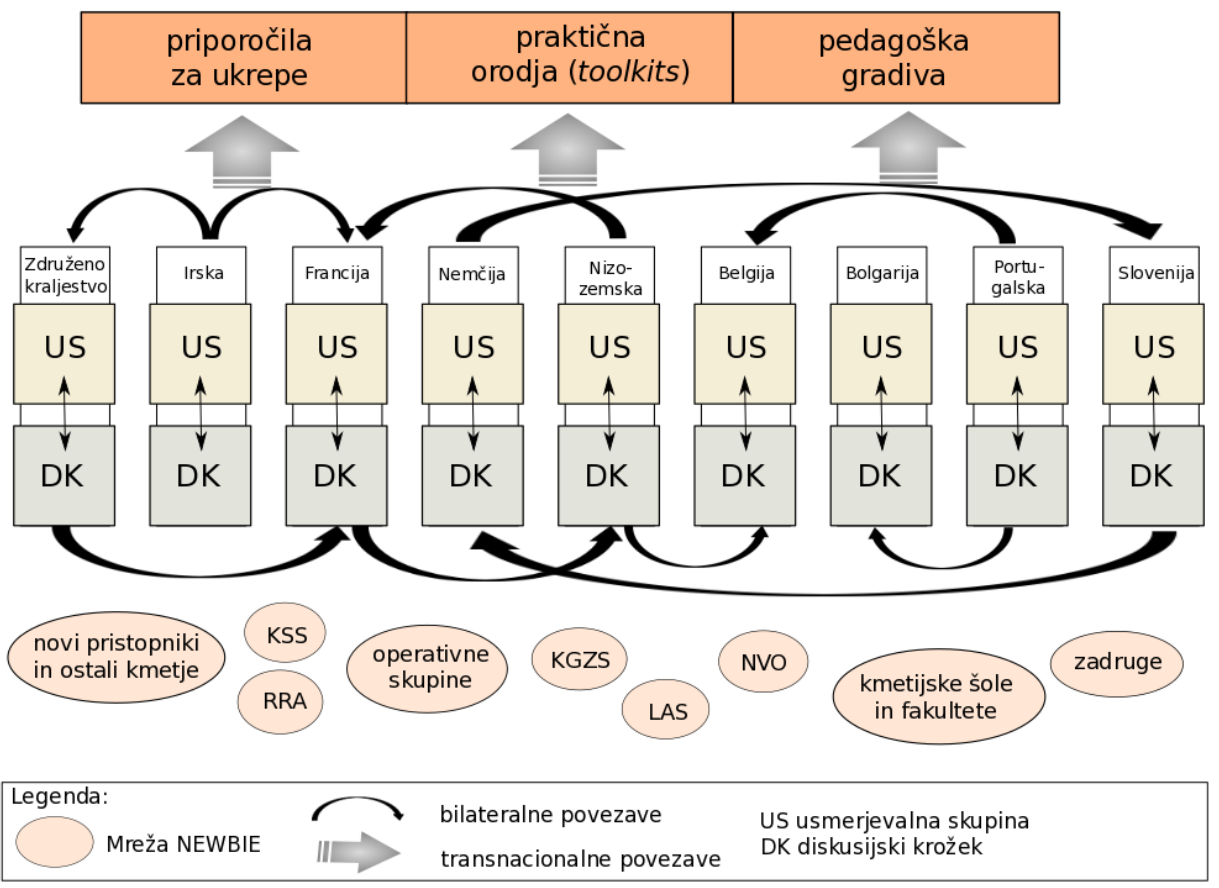

Projektno skupino usmerjajo sledeči cilji:

- zbrati, kritično ovrednotiti in objaviti informacije o obstoječih poslovnih in vstopnih modelih kmetij ter o možnostih za nove;

- spodbuditi izmenjavo praktičnih, izobraževalnih in strokovnih informacij o novih poslovnih in vstopnih modelih kmetij v različnih evropskih državah in krepiti trajno povezavo med prakso, formalnim in neformalnim izobraževanjem, svetovanjem in raziskavami na nacionalni in evropski ravni ter razviti dobro delujoče podporno okolje za nove pristopnike (svetovalne storitve, izobraževanja in usposabljanja);

- pripraviti in širiti informacije o vstopnih in poslovnih modelih kmetij s pomočjo tradicionalnih in alternativnih kmetijskih izobraževalnih in podpornih ustanov (kmetijskih svetovalnih služb, zadrug ali drugih združenj kmetov, kmetijskih šol in fakultet, operativnih skupin, programa LEADER, regionalnih in nacionalnih agencij) ter omogočiti dolgoročen dostop do informacij;

- $\quad$ z vzpostavitvijo usmerjevalne skupine (v katero so vključeni predstavniki relevantnih ustanov s področja kmetijstva) in organizacijo diskusijskih krožkov vzpodbuditi 
razpravo in iskanje rešitev za premostitev (pre)številnih ovir, s katerimi se sooča vsak, ki na novo vstopa v kmetijski sektor;

- $\mathrm{z}$ razvojem in s pripravo praktičnih orodij (t. i. toolkitov) ter priporočil za vzpostavitev novega ali izboljšanje obstoječega poslovnega modela na kmetiji povečati konkurenčnost novih pristopnikov in različnim akterjem v kmetijsko-živilski industriji približati nove vstopne in poslovne modele;

- $\quad$ z razvojem pedagoških gradiv zapolniti vrzel med dejanskimi potrebami kmeta ter obstoječimi pedagoškimi praksami in tako okrepiti (formalne) prenose znanja na različnih ravneh izobraževanja;

- spodbujati inovativne poslovne modele (npr. z objavo uspešnih zgodb, s podeljevanjem nagrade za najboljše poslovne modele novih pristopnikov, z mreženjem zainteresiranih slovenskih novih pristopnikov s tujimi), ki vodijo k povečanju gospodarske, okoljske in socialne prožnosti kmetij;

- s predstavitvijo zgodb uspešnih novih pristopnikov (vključno z virtualno knjižnico videozgodb) zagotoviti podporo za izvajanje Evropskega inovativnega partnerstva za produktivnost in trajnost na področju kmetijstva, živilstva in gozdarstva;

- prispevati relevantne informacije raziskovalnim programom in politikam o ovirah, s katerimi se spopadajo novi pristopniki v kmetijstvo, svetovati, kako jih premagati ter prispevati k razvijanju konkurenčnosti in prožnosti kmetijstva in s tem tudi podeželja v Evropi.

Celoten projekt je organiziran v več delovnih paketih. S popisom in analizo izbranih novih pristopnikov v vsaki državi želimo prepoznati in analizirati različne primere uspešnih vstopnih in poslovnih modelov novih pristopnikov v kmetijstvo. Z analizo delovanja svetovalnih storitev kmetijskih svetovalnih služb po državah partnericah bomo prepoznali uspešne modele izvajanja tistih, ki le-te že uporabljajo za podporo novim pristopnikom. Vsaka partnerska država bo predstavila deset primerov dobrih vstopnih in/ali poslovnih modelov novih pristopnikov. Skupaj bo predstavljenih 90 zgodb, ki bodo prispevale k obsežnejšemu pregledu in primerjavi stanja. Podporna mreža za nove pristopnike naslavlja vzpostavitev Mreže NEWBIE, v katero bodo povezani novi pristopniki, že uveljavljeni kmetje, združenja kmetov, kmetijske svetovalne službe, kmetijske izobraževalne ustanove, učitelji in raziskovalci, nevladne organizacije itd. Z različnimi aktivnostmi bo vsaka država partnerica prepoznala zanimive in hkrati tudi zainteresirane nove pristopnike in druge akterje, ki so povezani v kmetijstvom, ter jim ponudila priložnost seznaniti se z izkušnjami drugih partnerskih držav EU ter tako prenesti nova znanja in izkušnje v lastno kmetijsko prakso ali domači/slovenski prostor. Te izmenjave bodo potekale preko bilateralnih srečanj, tematskih obiskov in izobraževanj ter v okviru dveh mednarodnih dogodkov - konferenc v letu 2019 in 2021. Zbrane informacije bodo ključnega pomena pri pripravi orodij, priporočil in pedagoških gradiv za prenos novih spoznanj v pedagoške procese in politike (delovni paket Ključni dejavniki, orodja in smernice za uspešno implementacijo, ki ga vodi Oddelek za geografijo Filozofske fakultete Univerze v Ljubljani).

Kaj smo na Oddelku za geografijo že realizirali v uvodnem letu izvajanja projekta? Vzpostavili smo Usmerjevalno skupino in z njihovimi člani izvedli dva sestanka. V 
septembru 2018 smo izvedli prvi vsebinski Diskusijski krožek (v sklopu Srečanja slovenskih lokalnih akcijskih skupin v Mekinjah pri Kamniku), na katerem so se soočila mnenja, izkušnje in predlogi novincev, naslednikov, javnih ustanov, odločevalcev, lokalne samouprave, raziskovalcev in izobraževalnega sektorja. Razpravljali smo o ključni oviri, s katero se soočajo vsi novi pristopniki, tj. z (ne)razpoložljivostjo kmetijskih zemljišč v Sloveniji. V prihodnje bomo naslavljali še druge ovire, ki jih prepoznamo kot ključne pri vzpostavljanju novih poslovnih modelov, npr. kje in na kakšne načine dostopati do pravih znanj, kako zagotoviti ustrezna razvojna finančna sredstva itd. Izvedli smo deset polstrukturiranih intervjujev z novimi pristopniki v Sloveniji (zastopane so kmetije različnih predelovalnih usmeritev iz različnih pokrajinskih enot) ter razpisali »Nagrado NEWBIE«, s katero bomo tri leta zapored nagradili tistega novega pristopnika, ki nas bo s svojim poslovnim in/ali vstopnim modelom najbolj prepričal.

Projekt želi zainteresiranim in najširši javnosti preko dogodkov, spletne strani (povezava: www.newbie-academy.eu) in vključenosti v Mrežo NEWBIE omogočiti dostop do priporočil, usmerjenih v razvoj spodbudnega okolja za nove pristopnike v kmetijstvu in na podeželju, številnih dobrih praks iz držav partneric projekta (90 intervjujev in predstavljenih primerov v obliki videozgodb), novih sistemov prenosa znanj in učenja ipd.

Vsi, ki vas zanimajo novi pristopniki in njihovi poslovni modeli, ki v svojem okolju prepoznavate zanimive primere ali ste mogoče novi pristopnik celo sami, ki ste del njihovega podpornega okolja (občine, lokalne akcijske skupine, svetovalne službe, finančni in pravni ter izobraževalni sektor ipd.), ste lepo vabljeni, da se vključite v Mrežo NEWBIE (povezava: http://www.newbie-academy.eu/membership-si/). Le-to vam bo omogočilo, da spoznate vstopne in poslovne modele novih pristopnikov v drugih državah, primere reševanja ovir pri dostopu do zemljišč, kapitala, trga, informacij, delovne sile ipd.

Irma Potočnik Slavič, Barbara Lampič in Sara Uhan 
Spletna stran projekta NEWBIE.

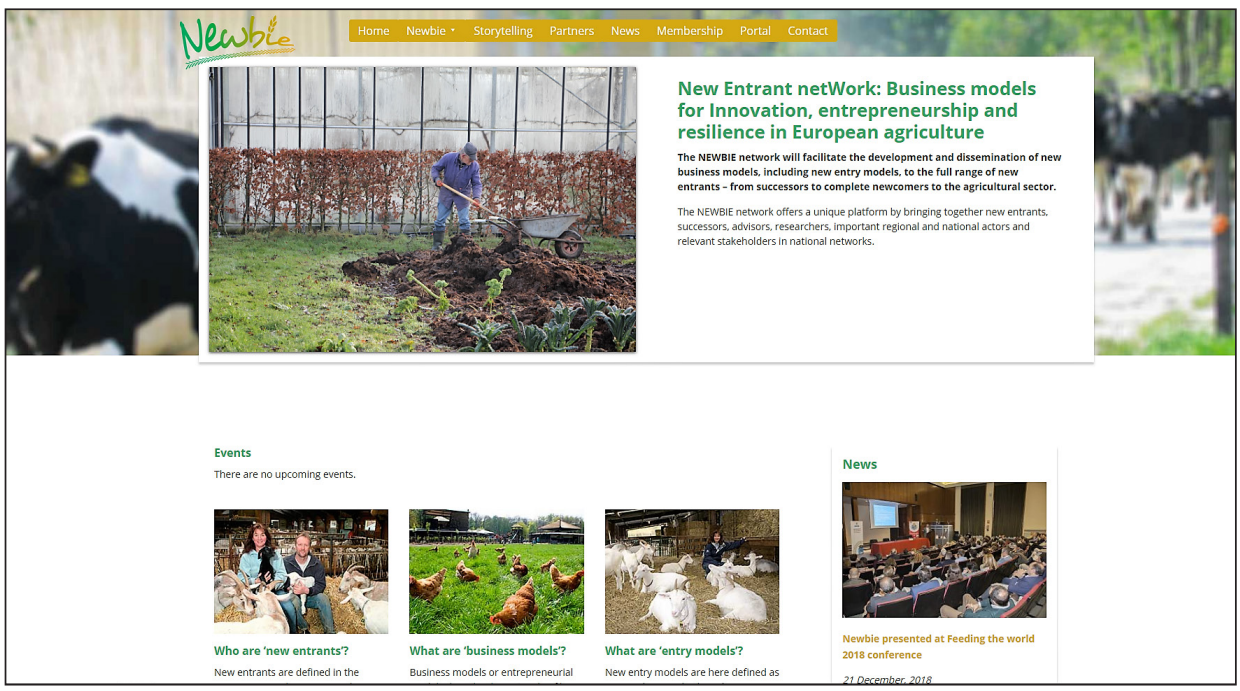

Predstavljene videozgodbe novih pristopnikov na spletni strani projekta NEWBIE.

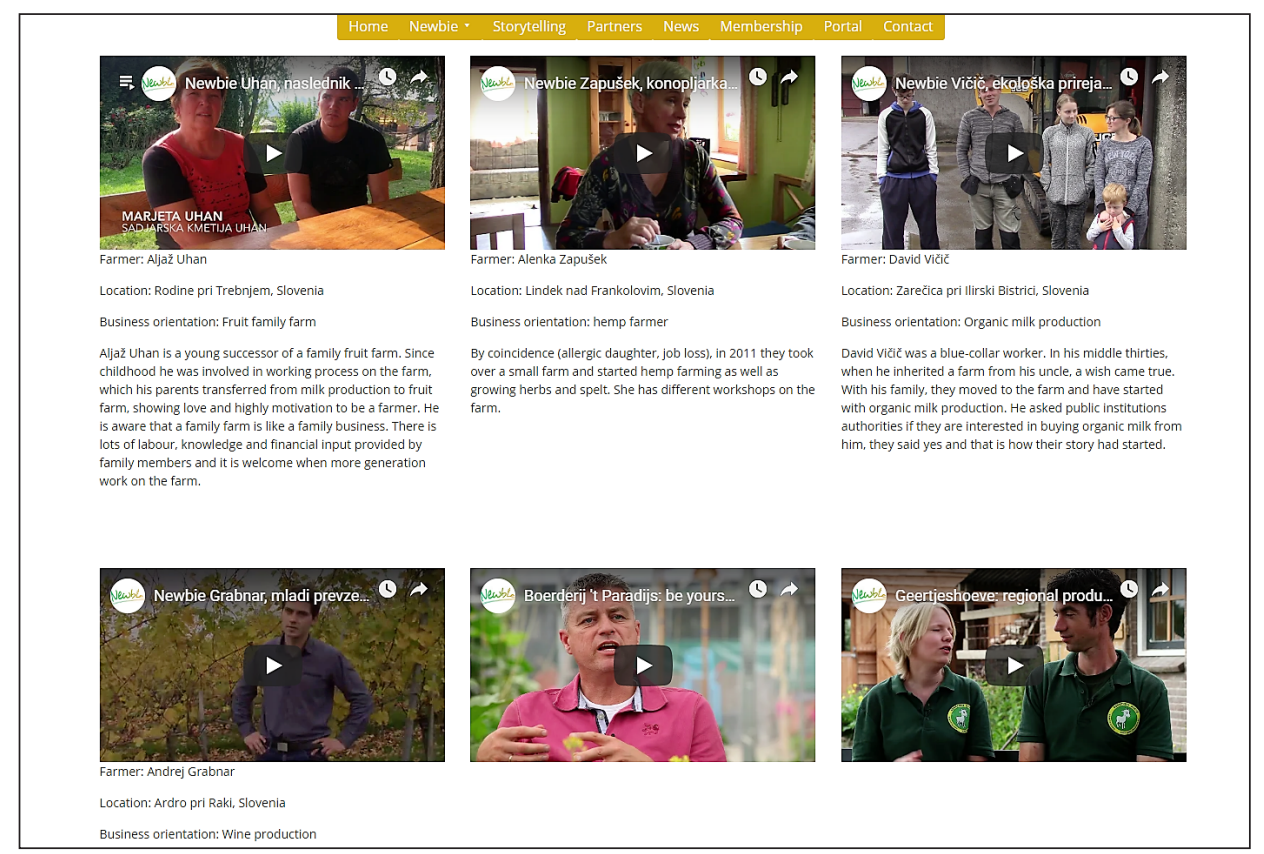

